\title{
Peculiarities of Accounting Non-Operational Assets by Budgetary Organizations
}

\author{
Dyachenko E.Yu. \\ Department of Accounting and Auditing \\ Emperator Peter the Great State Agrarian University \\ Voronezh, Russia \\ dorohova85@yandex.ru
}

\author{
Logvinova T. I. \\ Department of Accounting and Auditing \\ Emperator Peter the Great State Agrarian University \\ Voronezh, Russia \\ tam.logvinova@yandex.ru
}

\begin{abstract}
This article reflects the results of investigating the development of business accounting of non-operational assets in the organizations of the economy government sector. We determined accounting items related to this category of assets; made analysis of regulations as well as periodicals that highlight the problems of non-operational assets accounting. Taking into consideration changes in legislation, methodical elements of the inside local act of budgetary organization were elaborated. The structure of the account 010300000 "Non-produced assets" was improved, working schemes of account entries for using them in account activity of budget institutions were composed. In an effort to reveal additional information about non-operational assets in accounting (financial) reports, we designed a special form of Accounting balance sheet for means, received in quality of compensation for their price reduction, loss or disposal.
\end{abstract}

Keywords-non-operational assets; federal standard; budgetary organizations; international financial reporting standards (IFRS) for the public sector; non-financial assets.

\section{INTRODUCTION}

The organizations of the economy government sector represent a special group of commercial entities, what is determined by the specific character of assets at their disposal and operations carried out by them. From the point of view of economic dimension, non-produced assets are of great interest as they serve the basis of budgetary organizations activity and constitute a peculiar type of assets not produced by human beings. Improvement of regulatory framework of business accounting in budget organizations sets conditions for requirement in elaboration of detailed methodical recommendations concerning record keeping of particular assets and liabilities types. The purpose of this scientific research is reasoning of actual tendencies of improving the system of business accounting of non-produces assets that will contribute to increase of its informative and control functions.

\section{LITERATURE REVIEW}

Objectivity, reliability and understandability of account information for inside as well as outside users may be ensured in case of knowing main legislative and normative acts that regulate business accounting, because irrespective of organizational-legal form each economic agent carries out its activity in accordance with the Russian law [1].

In agreement with item 70 of Instruction No. 157n, nonproduced assets include items of non-financial assets, which are not production products; real property right to them must be assigned at the organization in accordance with the established procedure (land, mineral resources etc.), these assets are used by this organization in its activity [2].

At the same time, in the project of federal accounting standard (FAS), displayed on web site of Finance Ministry of the Russian Federation (RF) "Non-produced assets", this category of assets is defined as items of non-financial assets, which are not production products; real property right to them must be assigned in conformity with the established procedure (land, mineral resources etc.) [3].

It needs mentioning that this normative act was worked out in accordance with the Program of developing federal standards of business accounting for budgetary institutions [4].

Investigation of regulations of FAS project allowed us to make a conclusion about significant change in methodology of accounting non-produced assets [5].

\section{RESEARCH METHODOLOGY}

Primarily, Russian Finance Ministry actualized the structure of this asset, pointing out separate groups of water resources and uncultivated biological resources. In table 1, we systemized the items of business accounting of non-produced assets in compliance with their classification.

TABLE I. CLASSIFICATION OF NON-PRODUCED ASSETS AND DETERMINATION OF ACCOUNTING ITEM

\begin{tabular}{|l|l|l|}
\hline \multicolumn{1}{|c|}{ FAS project } & \multicolumn{1}{|c|}{$\begin{array}{c}\text { Current } \\
\text { Instruction No. } \\
\text { № 157n }\end{array}$} & \multicolumn{1}{|c|}{ Accounting item } \\
\hline Land (land plots) & Land & $\begin{array}{l}\text { Land plot or its part, with } \\
\text { characteristics which allow to } \\
\text { define it as an individually } \\
\text { determined thing }\end{array}$ \\
\hline Mineral resources & $\begin{array}{l}\text { Mineral } \\
\text { resources }\end{array}$ & $\begin{array}{l}\text { A section of mineral resources } \\
\text { with boundaries that are well- } \\
\text { defined and fixed in the license }\end{array}$ \\
\hline Water resources & - & Body of water provided for use at \\
\hline
\end{tabular}




\begin{tabular}{|l|l|l|}
\hline & & $\begin{array}{l}\text { a charge in accordance with the } \\
\text { contract }\end{array}$ \\
\hline $\begin{array}{l}\text { Uncultivated } \\
\text { biological } \\
\text { resources }\end{array}$ & $\begin{array}{l}\text { 1) Particular kinds of water } \\
\text { bioresources for which a general } \\
\text { permissible catch is set up; } \\
\text { 2) Items of fauna (wild animals), } \\
\text { with fixed limits of allowable } \\
\text { withdrawal from nature; } \\
\text { 3) Items of flora (forest areas, } \\
\text { located within the boundaries of } \\
\text { forest fund lands) }\end{array}$ \\
\hline $\begin{array}{l}\text { Other non-produced } \\
\text { assets }\end{array}$ & $\begin{array}{l}\text { Other non- } \\
\text { produced assets }\end{array}$ & $\begin{array}{l}\text { Objects which do not refer to the } \\
\text { named types of non-produced } \\
\text { assets (radio-frequency spectrum) }\end{array}$ \\
\hline
\end{tabular}

In the course of analyzing the modifications, introduced by the new FAS project into terminology, several authors, including Druzhilovskaya E.S., draw attention to absence of terms definition, which straightly relate to evaluation of such assets [6].

Along with modifications in terminology and structure, the FAS project determines the criteria for referring the assets to the category of "non-produced" ones:

1) the used item can bring economic benefits or have profitable potential (it is possible to predict this fact);

2) the initial cost of the item can be reliably estimated.

Herewith, the rules of forming the initial cost of assets depend on the ways of their receipt. We must note that fair value in the standard means a cadastral or discounted value as well as market valuation (for valuation of single land plots). In this context, the rules of their definition in the project are not regulated, and cadastral and fair values are considered identical.

Kurochkina L.P. in her scientific work points to the need of further evaluation of non-produced assets, including accounting of the costs for reconstruction, modernization and replacement of objects [7].

The studies have shown that the current regulatory act prescribes to refer the costs, connected with the reconstruction, modernization and replacement of facilities, to the increase of the initial cost of non-produced assets. Along with that, the FAS project provides for the attribution of such costs to the expenses of the current period.

Assets, classified as non-produced, are subject to their revaluation to the level of fair value. Herewith, for land plots it will be the cadastral value, and for all other objects - the amount of discounted future cash receipts associated with the use of these assets [8].

During the analysis of the FAS project regulations it was found that the regulatory act defines the requirements for determining the signs of loss in value of non-produced assets.

Non-produced assets along with other property of the organization in certain cases are subject to write-off. Upon this, the project standard establishes that an asset is subject to write-off from accounting if:
- sale, gratuitous transfer is made, i.e. property rights are terminated;

- the quality characteristic is changed;

- transfer to another budget organization is carried out.

In order to provide useful and reliable data to interested users, information on each group of non-produced assets shall be disclosed in the accounting (financial) statements. Herewith, the basic statement forms should reflect the sum of carrying amount and the sum of cumulative impairment nonproduced assets losses at the beginning and end of the year, as well as the residual value of the properties. Additional information is subject to disclosure in the Notes to the annual report.

It should be noted that the procedure for establishing and securing real property rights to non-produced assets is one of the main activities of budget organizations.

Zakharyin V.R. mentions that in general case nonfinancial assets in institutions are on the right of operational management. The exception is land plots, the transfer of which to the operational management is not allowed by land legislation (Land code of the Russian Federation) [9].

In our study we used such methods as analysis and synthesis, analogue method, comparison, grouping, logical and systematic approach.

\section{RESULTS}

Reconstruction of business accounting of state-funded organizations has direct influence on the formation of internal local acts by these economic subjects.

Having studied the regulations of FAS project "Nonproduced assets", we have developed methodological elements of accounting policy for public sector organizations (table 2).

TABLE 2. RECOMMENDED METHODOLOGICAL SECTION OF THE INTERNAL LOCAL ACT REGARDING THE ACCOUNTING OF NONPRODUCES ASSETS

\begin{tabular}{|l|l|}
\hline \multicolumn{1}{|c|}{$\begin{array}{c}\text { Element of accounting } \\
\text { policy }\end{array}$} & \multicolumn{1}{|c|}{ Contents } \\
\hline $\begin{array}{l}\text { Criteria for attribution } \\
\text { of property to non- } \\
\text { produced assets }\end{array}$ & $\begin{array}{l}\text { 1) The object used is able to bring economic } \\
\text { benefits or have a useful potential (it is possible to } \\
\text { predict this fact); } \\
\text { 2) The initial value of the object can be reliably } \\
\text { estimated. }\end{array}$ \\
\hline Methods of receipt & $\begin{array}{l}\text { 1) Involvement in economic turnover for the first } \\
\text { time; } \\
\text { 2) Acquisition as a result of exchange operations; } \\
\text { 3) Acquisition by transaction of exchange for } \\
\text { non-financial assets or a combination of financial } \\
\text { and non-financial assets; } \\
\text { 4) Acquisition by non-exchange transaction; } \\
\text { 5) Receipt by the subject of accounting from the } \\
\text { owner (founder). }\end{array}$ \\
\hline $\begin{array}{l}\text { Formation of initial cost } \\
\text { at recognition of assets } \\
\text { in accounting }\end{array}$ & $\begin{array}{l}\text { Depending on a method of assets receipt and their } \\
\text { classification group }\end{array}$ \\
\hline Unit of accounting & \begin{tabular}{l} 
Inventory number \\
\hline Subsequent assessment
\end{tabular} \\
$\begin{array}{l}\text { The costs of reconstruction, modernization, } \\
\text { replacement of objects are reflected in the current } \\
\text { period expenses without increasing the original } \\
\text { cost of objects. }\end{array}$ \\
\hline
\end{tabular}




\begin{tabular}{|l|l|}
\hline Revaluation & $\begin{array}{l}\text { Items are revalued to fair value. The revaluation } \\
\text { amount is charged to the financial result as } \\
\text { income or expense for the current period. Held } \\
\text { annually. }\end{array}$ \\
\hline Depreciation & $\begin{array}{l}\text { To depreciation is charged. } \\
\text { apply the regulations of the Federal standard } \\
\text { "Impairment of assets". Impairment or loss are } \\
\text { separate economic events and they are taken into } \\
\text { accounted separately. }\end{array}$ \\
\hline $\begin{array}{l}\text { Write-off from } \\
\text { accounting }\end{array}$ & $\begin{array}{l}\text { If by the organization: } \\
\text {-sale, gratuitous transfer is made, i.e. property } \\
\text { rights are terminated; } \\
\text {-the quality characteristic is changed; } \\
\text {-transfer to another budget organization is carried } \\
\text { out. }\end{array}$ \\
\hline $\begin{array}{l}\text { Disclosure information } \\
\text { financial statements }\end{array}$ & $\begin{array}{l}\text { The balance sheet and the statement of financial } \\
\text { results reflect the amount of the carrying amount } \\
\text { and the amount of accumulated impairment losses } \\
\text { of non-produces assets at the beginning and end } \\
\text { of the year, as well as the residual value of the } \\
\text { objects. } \\
\text { The explanatory note discloses additional } \\
\text { information on non-produced assets (amounts of } \\
\text { investments in the acquisition of assets, amounts } \\
\text { of compensation for depreciated, lost or } \\
\text { transferred property, etc.) }\end{array}$ \\
\hline
\end{tabular}

In accordance with Instruction No. $157 \mathrm{n}$ for accounting non-produced assets the same-name account is meant 010300 000 [2]. In order to organize an effective accounting system, we recommend providing analytical positions to this synthetic account (table III).

TABLE III. RECOMMENDED STRUCTURE OF ACCOUNT 010300000 "NON-PRODUCED ASSETS"

\begin{tabular}{|l|c|c|c|}
\hline \multicolumn{1}{|c|}{ Name of account } & $\begin{array}{c}\text { Account } \\
\text { object (class } \\
19-21)\end{array}$ & $\begin{array}{c}\text { Group } \\
\text { (class 22) }\end{array}$ & $\begin{array}{c}\text { Type } \\
\text { (class } \\
23)\end{array}$ \\
\hline Non-produced assets: & $\mathbf{1 0 3}$ & $\mathbf{0}$ & $\mathbf{0}$ \\
\hline Land (land plots) & 103 & 1 & 0 \\
\hline Mineral resources & 103 & 2 & 0 \\
\hline Water resources & 103 & 3 & 0 \\
\hline Uncultivated biological resources: & 103 & 4 & 0 \\
\hline - water bioresources & 103 & 4 & 1 \\
\hline - animal bioresources & 103 & 4 & 2 \\
\hline - objects of flora & 103 & 4 & 3 \\
\hline Other non-produced assets & 103 & 5 & 0 \\
\hline
\end{tabular}

It is necessary to note that the type of a synthetic account will vary depending on the available non-produced assets in the organization. Thus, when accounting mineral resources in the $23^{\text {rd }}$ class of the account, it is advisable to reflect the type of the extracted asset (1-coal, 2-oil, 3-gas etc.).

The last three symbols in the structure of the account will change according to the facts of economic life.

Taking into account the proposed structure of the account 010300000 "Non-produced assets", we have formed working accounting records to reflect transactions with this property (table IV).
TABLE IV. RECOMMENDED SCHEMES OF ACCOUNTING RECORDS FOR THE REFLECTION OF TRANSACTIONS WITH NON-PRODUCED ASSETS IN THE ACCOUNT (BY THE EXAMPLE OF LAND PLOTS)

\begin{tabular}{|c|c|c|}
\hline Economic event & Debit of accounts & Credit of accounts \\
\hline $\begin{array}{l}\text { Lands for temporary use } \\
\text { are received from the } \\
\text { founder }\end{array}$ & $\begin{array}{c}310310330 \\
\text { "Increase in land cost" }\end{array}$ & $\begin{array}{c}310613410 \\
\text { "Reduction of } \\
\text { investments } \\
\text { in non-produced } \\
\text { assets" }\end{array}$ \\
\hline $\begin{array}{l}\text { Expenses on acquisition } \\
\text { of land plots are reflected }\end{array}$ & $\begin{array}{c}210613310 \\
\text { "Increase in } \\
\text { investments } \\
\text { in non-produced } \\
\text { assets" }\end{array}$ & $\begin{array}{c}230233730 \\
\text { "Increase in accounts } \\
\text { payable on } \\
\text { acquisition of non- } \\
\text { produced assets" }\end{array}$ \\
\hline $\begin{array}{l}\text { Lands, acquired at the } \\
\text { expense of income- } \\
\text { generating activities, are } \\
\text { taken into account }\end{array}$ & $\begin{array}{c}210310330 \\
\text { "Increase in land cost" }\end{array}$ & $\begin{array}{c}210613410 \\
\text { "Reduction of } \\
\text { investments } \\
\text { in non-produced } \\
\text { assets" }\end{array}$ \\
\hline $\begin{array}{l}\text { Cadastral value of land, } \\
\text { received in perpetuity, is } \\
\text { reflected }\end{array}$ & $\begin{array}{c}410310330 \\
\text { "Increase in land cost" }\end{array}$ & $\begin{array}{c}440110180 \\
\text { "Other income" }\end{array}$ \\
\hline $\begin{array}{l}\text { The value of land is } \\
\text { changed as a result of } \\
\text { increasing their cadastral } \\
\text { price }\end{array}$ & $\begin{array}{c}010310330 \\
\text { "Increase in land cost" }\end{array}$ & $\begin{array}{l}040110180 \\
\text { "Other income", }\end{array}$ \\
\hline $\begin{array}{l}\text { Markdown (revaluation) } \\
\text { of the land cost is carried } \\
\text { out }\end{array}$ & $\begin{array}{c}040130000 \\
\text { "Financial result } \\
\text { of last accounting } \\
\text { periods" }\end{array}$ & $\begin{array}{c}010310000 \\
\text { "Non-produced assets } \\
- \\
\text { and (land plots)" }\end{array}$ \\
\hline $\begin{array}{l}\text { Gratuitous transfer of land } \\
\text { to other budget } \\
\text { organizations is reflected }\end{array}$ & $\begin{array}{c}040120241 \\
\text { "Expenses on } \\
\text { gratuitous transfers to } \\
\text { the state and municipal } \\
\text { organizations" }\end{array}$ & $\begin{array}{c}010310430 \\
\text { "Reduction of land } \\
\text { cost" }\end{array}$ \\
\hline $\begin{array}{l}\text { Land is sold to budget } \\
\text { institution }\end{array}$ & $\begin{array}{l}240110172 \\
\text { "Income from } \\
\text { operations } \\
\text { with assets" }\end{array}$ & $\begin{array}{c}210310430 \\
\text { "Reduction of land } \\
\text { cost" }\end{array}$ \\
\hline $\begin{array}{l}\text { Impairment of land due to } \\
\text { deterioration of its } \\
\text { qualitative characteristics } \\
\text { is reflected }\end{array}$ & $\begin{array}{c}040120274 \\
\text { "Land impairment } \\
\text { losses" }\end{array}$ & $\begin{array}{c}011461432 \\
\text { "Reduction of land } \\
\text { cost } \\
\text { due to impairment" }\end{array}$ \\
\hline
\end{tabular}

The researches show that in order to control the compliance of accounting data with the actual presence of non-produced assets in the context of their classification groups, budget institutions prepare a turnover balance sheet for non-financial assets [10]. The register of synthetic accounting is the journal of operations on disposal and movement of non-financial assets and the Journal of other operations. Information from these accounting registers is be reflected in the basic forms of accounting (financial) statements [11,12]. However, certain information on transactions with non-produced assets, being of economic interest to different groups of users, should be disclosed as an explanation to the annual report.

In order to reflect additional information about the funds, received from the owner (founder) to compensate for the impairment and loss of non-produced assets, as well as about income from the transfer of property to other public sector organizations, we have modeled the corresponding Report (table V). 
[3] Draft federal standards for the public sector. URL: http:// minfin.ru/ ru/perfomance/ budget/ bu_gs/sfo/.

TABLE V. REPORT ON COMPENSATIONS RECEIVED BY THE BUDGET INSTITUTION DURING THE CURRENT YEAR (RUB.)

\begin{tabular}{|l|c|c|c|}
\hline $\begin{array}{c}\text { Name of the non- } \\
\text { produced asset }\end{array}$ & $\begin{array}{c}\text { Compensation } \\
\text { from the owner } \\
\text { (founder) } \\
\text { related to } \\
\text { impairment }\end{array}$ & $\begin{array}{c}\text { Compensation } \\
\text { from the } \\
\text { owner } \\
\text { (founder) } \\
\text { related to loss }\end{array}$ & $\begin{array}{c}\text { Income } \\
\text { from the transfer } \\
\text { of assets to other } \\
\text { budget } \\
\text { organizations }\end{array}$ \\
\hline $\begin{array}{l}\text { Land } \\
\text { (cadastral number } \\
10002: 21)\end{array}$ & 300000 & - & - \\
\hline $\begin{array}{l}\text { Land } \\
\text { (cadastral number } \\
10004: 15)\end{array}$ & - & - & 500000 \\
\hline $\begin{array}{l}\text { Forest plot No. 3 sq. } \\
2 \text { ha }\end{array}$ & & 452000 & \\
\hline Total & 300000 & 452000 & 500000 \\
\hline
\end{tabular}

It should be mentioned that the developed form of the report can be included into the report on financial results, as explanations to it, or can be presented in explanations to accounting (financial) statements.

\section{DISCUSSION}

In the course of our research, we came to the conclusion that non-produced assets represent a special category of property of public sector organizations. The development of Federal Accounting Standard introduces significant changes in the accounting of this category of assets, which necessitates the updating of internal local acts. The proposed methodological elements of accounting policy allow to improve the system of normative documents used by budgetary institutions in their activities.

Taking into account the classification of non-produced assets, we improved the structure of the same-name synthetic account $0 \quad 10300000$. The proposed business accounts allowed to form models of working accounts to reflect the economic events of budgetary organizations.

The necessity to provide reliable and useful information to the interested users determines the advisability to develop reports, including those ones, which disclose additional information about compensation and income received from various contractors.

\section{CONCLUSION}

The conducted research and developed recommendations will permit to improve the reliability of accounting and reporting information on the operations of public sector organizations with non-produced assets. The proposed directions of improving the accounting system of this category of property contribute to making effective decisions and satisfying information requests of users.

\section{References}

[1] V.B. Malitskaya. Legal framework for regulation of accounting and disclosure in financial statements of transactions with financial assets. Terra Economicus. 2010, vol. 8, 2-2, pp. 281-288.

[2] About the approval of the Single plan of accounts for public authorities (government bodies), local authorities, management bodies of state extrabudgetary funds, state academies of sciences, state (municipal) institutions and Instructions for its use: Order of the Ministry of Finance of Russia dated 01.12.2010, No. 157n. URL: http://www.consultant.ru.
[4] The program of development of federal accounting standards for public sector organizations: approved by the Order of the Ministry of Finance of the Russian Federation dated 10.04.2015 No. 64n. URL: http://www.consultant.ru.

[5] E.S. Druzhilovskaya. A new stage of reforming the accounting in Russia. Accountant and Law. 2014, 3, pp. 2-13.

[6] E.S. Druzhilovskaya. Theoretical and methodological problems of valuation of non-produced assets in accounting and ways of their solution. Accounting in budgetary and non-profit organizations. 2017, 8, pp. 2-24.

[7] L.P. Kurochkina. Changes in accounting of non-financial assets of the budgetary institution. Accounting in budgetary and non-profit organizations. 2009, 7, pp. 11-22.

[8] A.Yu. Opalsky. Accounting of non-financial assets. Accounting and taxation in budgetary organizations. 2011, 10, pp. 11-17.

[9] V.R. Zakharyin. Accounting of non-produced assets. Accounting in budgetary institutions. 2015, 6, pp. 15-18.

[10]S.A Zvyagin, T.N. Fomenko, N.A. Breslavtseva, A.A. Fedchenko. Study of objects during the accounting expertise in the economic organizations of public sector. Research Journal of Pharmaceutical, Biological and Chemical Sciences. 2018, vol. 9, 6, pp. 1961-1970.

[11]Alexsandr S. Kuznetsov. Russian Professor's meeting. Russian Journal of Physical Education and Sport. 2019, 14(1), pp. 17-22. DOI: 10.14526/2070-4798-2019-14-1-18-24

[12]T.I. Logvinova, E.Yu. Dyachenko. Disclosure of information in the financial statements of budgetary institutions of higher professional education based on information requests of users. Audit and financial analysis. 2014, 3, pp. 63-69. 